\title{
Split over 'privatization' of UK observatories
}

London. Plans for 'privatizing' the management of Britain's overseas observatories and telescope development activities have apparently been delayed by sharp differences at top levels of government over how much of the costs involved should be taken out of the science budget.

Scientists are concerned at the prospect of having to cut back on research programmes to cover an estimated $£ 12$ million (US\$20 million) in pension commitments to observatory staff that would have to be included in any privatization package. Whether this should happen is reported to be a heated point of discussion over next year's budget for the whole Department of Trade and Industry (DTI), due to be announced next week as part of the government's budget for next year.

Plans to invite bids from private organizations and others for managing the Royal Greenwich Observatory and the Royal Observatory of Edinburgh, as well as telescopes in Hawaii and the Looking for an answer: Heseltine (left) and Waldegrave Canary islands, were first announced by (right) are said to disagree over paying for pensions. the government earlier this year (see Nature 381, 3; 1996).

Interested bodies include the University of Cambridge, where the Greenwich observatory is now based, and the University of Edinburgh, as well as the Central Laboratory of the Research Councils (CLRC) previously the Daresbury and Rutherford Appleton Laboratories.

Invitations for tender had been due to be sent out at the end of October. But this was delayed last week for a second time. No official reason has been given. But it is widely rumoured that a large stumbling block is the question of the pensions liability.

Indeed, the whole issue of who should pay for the costs of pension transfers associated with the privatization of research institutes has become a bone of contention between the Treasury, worried about extra financial commitments, and ministers keen to see the management of Britain's science opened up to market forces.

\section{IMAGE UNAVAILABLE FOR COPYRIGHT REASONS}

The latter is being actively pursued by Michael Heseltine, deputy prime minister, who, in his previous position as President of the Board of Trade, was responsible for privatizing bodies such as the Warren Spring Laboratory and the National Physical Laboratory (see Nature 376, 206; 1995).

Ironically, the Treasury's position is being defended by William Waldegrave, its chief secretary, who as a former Chancellor of the Duchy of Lancaster - and as such responsible for the Office of Science and Technology - showed himself sympathetic to the need for government support for basic science.

Peter Levene, a prominent industrialist who has been working for several years as the government's 'efficiency' expert, told the House of Commons select committee on science and technology last week that the pensions question was a 'highly complex issue', on which he had been asked to prepare a report for a cabinet committee.

But Levene refused to tell committee

$\frac{\vec{\omega}}{\hat{n}}$ members of his conclusions, on the

grounds that advice to ministers is

confidential. Neither would he be

is drawn by claims from Labour party

committee members that the govern-

हु ment's determination to privatize the

\& running of laboratories was based as

Фั. much on ideology as practicality.

The Particle Physics and Astronomy Research Council is already known to be concerned about the legal and other costs of privatizing the management of the telescopes, which will have to be paid for out of its annual allocation. Although an official government statement said that these totalled $£ 270,000$ so far, informal estimates are that the final bill - given the need to brief US and Spanish lawyers concerning telescopes in Hawaii and the Canary Islands — could be as high as $£ 2$ million.

Others remain opposed on principle to the privatization of the running of the observatories. "The whole process has become unnecessarily cumbersome, and the best outcome would still be if it was abandoned," says Sir Martin Rees, the Astronomer Royal and Royal Society Research Professor at the University of Cambridge. David Dickson

\section{BSE meeting reflects growing distrust of expert panels}

London. The 'mad cow' crisis has exposed the need to reform Britain's system for providing scientific expertise to the government by making expert committees more representative and open, according to speakers at a meeting of politicians, public health officials, and farming and consumer organizations in London this week.

The meeting, entitled 'BSE: a sickness of government?', also heard proposals that the Ministry of Agriculture, Fisheries and Food (MAFF) should no longer have responsibility for animal welfare and its consequences for public health.

The meeting was organized by Charter 88 , a body committed to constitutional reform. It appeared to confirm that the BSE crisis has increased public mistrust of the traditional idea that the safety of products can be adequately ensured by the existing system of expert committees. "Consumers have no confidence in the decision-making system that is supposed to protect us", said
Sheila McKechnie, director of the UK Consumers' Association.

Critics pointed out that, up to last December, the government's Spongiform Encephalopathy Advisory Committee (SEAC) did not include a single representative of the public health service. The meeting was told that there is a need to broaden the expertise of advisory committees, and in particular to include representatives of consumer organizations.

McKechnie says that the Consumers' Association has repeatedly asked MAFF for representation on SEAC and other advisory committees, but that its requests have always been refused on the grounds that it was not feasible, and that "we wouldn't understand the science". Consumer bodies can help "by asking the right questions" while gaining access to information.

Hugh Bayley, Labour member of Parliament for York, proposed that the minutes of all expert committees - except those concerning national defence or similar restricted issues - should be made public, and that such minutes should record conflicting positions on issues.

Several speakers expressed concern that the media might create scares by handling such information irresponsibly. But the general mood of the meeting was one of criticism of what was described as the "closed" nature of scientific decisionmaking within government, and a feeling that greater public scrutiny was needed. The BSE crisis, Bayley said, had been a tale of "incompetence" by the government, and "impotence" on the part of parliament.

Much of the criticism at the meeting centred on the perceived conflict of interest in handling health issues within the MAFF. The Consumers' Association says that it is drawing up detailed proposals for a separate food agency that would be independent of both industrial and agricultural interests.

Declan Butler 